\title{
International Market Integration and competitiveness of Indian Sugar
}

\begin{abstract}
Globalisation and liberalisation policies facilitated commodity markets of national and international to integrate with each other. This integration facilitated price transmission and market efficiency of commodities at domestic markets leading traders across the globe to exploit opportunities. India is one of the vibrant and emerging economies in the world by absorbing these economic features and integrating its markets with world. This paper focusing on Indian sugar market explores market integration of sugar prices with US, UK and Global average prices and also contributes a policy dimension to enhance competitiveness of Indian sugar sector. The paper using Johansen's co integration with Vector Error Correction Model finds existence of market integration of Indian sugar prices with international prices. However, Indian average sugar prices were found to be higher than other markets, with the support of Indian Government, motivating to increase sugar production in the country. The lower cane prices of Brazil, Australia and Thailand posing challenge in international markets for Indian sugar. However, Indian sugar sector has a competitive advantage of becoming a great energy source by focusing ethanol production leading to reduce international dependency for oil supplies. In addition, the sector can also contribute for rural socio-economic development by adopting technology to produce other by-products rather than mere concentrating on sugar.
\end{abstract}

Keywords: Market Integration; Sugar; Ethanol; Casual relationship; Global sugar 


\section{Introduction}

Commodity markets are integrating with developing and underdeveloped economies with the advent of globalisation and liberal trade policies at a global level. Improved technology, logistics and supply chains with encouraging government policies influence movement of commodities with lower transactional costs leading to cheaper imports by trade partners. Increasing complexity of integration makes it difficult to measure market efficiency. However, price of commodities acts as an indispensable tool to measure effectiveness of market integration at different levels (Saji, 2018). Market integration facilitates in assessing impact of market development, liberalization policies and contribute significantly for alleviating poverty (Timothy et al., 2014). An ideal market integration mechanism and absolute price transmission are important features required for effective marketing system. It eliminates arbitrage and facilitates in price transmission by removing price disparity. Indian agricultural system is hindered by poor infrastructure and lack of awareness for improving market efficiency (Praveen \& Inbasekar, 2015). Therefore, market transformation is essential for economic development and trade liberalization for underdeveloped and developing economies. Increase in international commodity prices fostered a greater interest in understanding market integration of domestic and international markets. Surge in prices acts as an opportunity as well as threat for economies with abundant natural resources. This situation provides an opportunity for deepening integration of prices between domestic and international markets. Weak integration is followed by decline in domestic supply during higher commodity prices (Varela et al., 2013). The issue of market integration is a view point to many debates on price policy, trade liberalization and reforms of state trading agencies. In India, integration of food commodities is limited to pulses and edible oil. Most of the external trade is channelized through state trading agencies (Sekhar, 2012).

Sugar is an important commodity in the global agricultural market with total production of 185.9 million tons and consumption of 176.8 million tons during the year 2018-19 (USDA, 2019). It is one of the largely traded commodities across the world with more government intervention, large price fluctuations, widespread production in many parts of the world (FAO, 1997). The major sugar producing countries are Brazil (38.87 million tons), India (32.45 million tons), European Union (21.15 million tons), Thailand (13.73 million tons) and China (10.25 million tons). Sugar, being an essential commodity is an important agro-based industrial sector contributing for the rural and economic development of the nation. India being the second largest producer of sugar, accounting to $15 \%$ of global sugar production and also one 
of the largest consumers (DFPD, 2019). The sector provides livelihood to 50 million sugar cane farmers and direct employment to more than five hundred thousand workers at sugar mills. In addition, the sector also contributes in developing indirect employment opportunities in rural and urban areas through ancillary activities of transportation, logistics and supply chain, agriinputs and trade etc.

\section{Figure 1: Word Production (Million tons)}

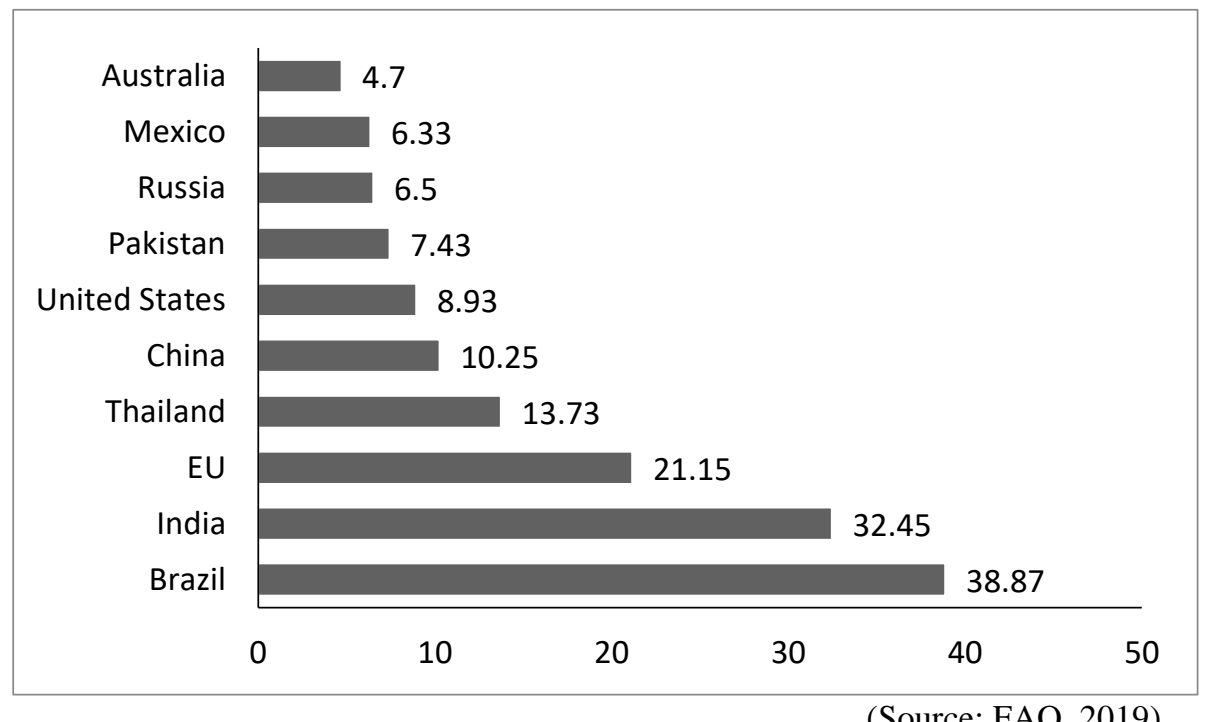

In India, sugar is largely cultivated in the states of Uttar Pradesh, Maharashtra and Karnataka. In Uttar Pradesh, production accounted to 57.6 MT during 2010-11 and in 2016-17, 88 MT of sugar was produced. In 2010-11, 90.7 MT of sugar was produced by Maharashtra and in 201415 the contribution of sugar from Maharashtra alone accounted to 105.2 MT. However, during 2016-17 it accounted to 41.9 MT that showed a significant plunge in production. The production of sugar in Karnataka during 2010-11 was 36.4 MT whereas in 2016-17 it accounted to 21.4 MT that indicated a gradual decrease in production.

Table 1: State wise production of sugar

\begin{tabular}{|l|c|c|c|c|c|c|c|}
\hline State & 2010-11 & 2011-12 & 2012-13 & 2013-14 & 2014-15 & 2015-16 & 2016-17(E) \\
\hline Uttar Pradesh & 57.6 & 69.6 & 75 & 66.1 & 71.4 & 68.5 & 88 \\
\hline Maharashtra & 90.7 & 90 & 79.9 & 77.2 & 105.2 & 86.1 & 41.9 \\
\hline Karnataka & 36.4 & 38.7 & 34.4 & 41.6 & 49.9 & 40.5 & 21.4 \\
\hline Others & 58.9 & 65.3 & 62.5 & 70.8 & 67.3 & 64.5 & 56.5 \\
\hline
\end{tabular}

In 2014-15, the production of sugar in the world was 1,77,582 MT, however, there was drastic fall in production upto 1,64,868 MT during 2015-16. On the other hand, consumption of sugar 
over the years is increasing globally. In 2017-18, the production and consumption accounted to $1,94,496 \mathrm{MT}$ and $1,73,584 \mathrm{MT}$ respectively. Similarly, in India during 2014-15, 30,460 MT of sugar was produced. However, in 2016-17, there was decline in production by $19 \%(22,200$ MT). Further in 2017-18, 34,309 MT was produced. The consumption of sugar in the country was 26500 MT during 2014-15 and there was a slight decline in production during 2016-17 accounting to 25,500 MT (USDA, 2019).

Table 2: Global and Indian Scenario of Sugar

\begin{tabular}{|c|c|c|c|c|c|c|}
\hline \multirow{2}{*}{ Year } & \multicolumn{3}{|c|}{ Global } & \multicolumn{3}{c|}{ India } \\
\cline { 2 - 7 } & Production & Consumption & $\begin{array}{c}\text { Surplus } \\
\text { /Deficit }\end{array}$ & Production & Consumption & $\begin{array}{c}\text { Surplus/ } \\
\text { Deficit }\end{array}$ \\
\hline $2014-15$ & $1,77,582$ & $1,68,037$ & 9,545 & 30,460 & 26,500 & 3,960 \\
\hline $2015-16$ & $1,64,868$ & $1,69,466$ & $-4,598$ & 27,385 & 26,800 & 585 \\
\hline $2016-17$ & $1,74,030$ & $1,70,816$ & 3,214 & 22,200 & 25,500 & $-3,300$ \\
\hline $2017-18$ & $1,94,496$ & $1,73,584$ & 20,912 & 34,309 & 26,500 & 7,809 \\
\hline $2018-19$ & $1,78,926$ & $1,73,952$ & 4,974 & 33,070 & 27,500 & 5,570 \\
\hline $2019-20$ & $1,80,734$ & $1,76,449$ & 4,285 & 30,305 & 28,500 & 1,805 \\
\hline
\end{tabular}

(Source: USDA, 2019)

Realization of remunerative prices for farmers' harvest is essential for remaining in farming activities. However, it is a challenging task to realize remunerative prices due to controllable and uncontrollable factors. Agri-commodities had wide market across the globe and it is determined with national and international developments. Sugar producers usually sell their produce to the sugar mills. Increased production of sugar in the country resulted to decline prices of sugar affecting livelihood of sugar farmers. This resulted to increase in the dues of sugar mills as they do not have the capacity to clear the dues during lower prices. The sugar prices at London and US commodity markets subjected to price volatility and moves upward/downward direction impacting global market integration. This necessitates to understand market integration for taking appropriate measures to manage price fluctuations and benefit from the price movements. It is, therefore, imminent to understand degree of integration of Indian sugar prices with International markets. The remaining part of this paper is structured as follows: section -2 describes scholastic review and objectives; section 3 provides theoretical framework; section -4 explains data and methodology; section -5 deals with analysis followed by discussion at section -6 , further, section 7 presents conclusion with future scope of research and section 8 describes managerial implications. 


\section{Review of Literature}

This paper reviewed scholastic evidences on Indian sugar industry, market integration and price transmission of sugar in internationally indexed journals of ABDC, ABS, Scopus and Web of Science. Jati (2013) studied dynamic relationship and impact of macroeconomic variables on sugar prices amongst Brazilian, Indian, French and Indonesian by employing impulse response function and variance decomposition. The results found variability of sugar prices at Brazil, India and Indonesia and their government's protective policies to sugar industry from macroeconomic shock. Upreti et al. (2018) examined price behaviour and market integration of sugar in India and sugar producing states of Uttar Pradesh and Maharashtra and found absence of co-integration. Timothy et al. (2014) examined the existence of integration among the selected sugar markets in Kenya by employing co-integration analysis and revealed factors such as road networks, consumer's purchasing power, communication networks and the distance between markets influenced market integration. Mishra and Kumar (2013) analysed the spatial integration of vegetable markets in Nepal using vector error correction model. The study found perishability and distance between markets of wholesale and retail reduces integration. Praveen and Inbasekar (2015) reviwed integration of cerals and perishibels of selected agricultural commodities in India and found that cerelas like rice and wheat showed better integration than perishables. Similarly, Boffa and Varela (2019) examined pattrens of spatil market integration and its determinants of food commoditities in India. The results revealed food markets are imperfectly integrated across the world with law of one price being symmetriaclly rejected. In addition, there exists significant co-movement between wholsale and reatil prices of commodities, but rice shows vertical integration. The critical issues of agricultural supply chain integration were assessed by Parwez (2016). It is revealed that efficient supply chain plays a significant role for the up-liftment of agricultural system. In addition, the support of government, corporate and institutions in integration of supply chain, sound management practices and infrastructure shall improve efficiency and effectiveness. Tankari (2012) analysed the global price transmission of sengal groundnut markets. The analysis showed non existence of long-run relationship between groundnuts price of Dakra, Kaolack and Fatick. Baquedano, et al. (2011) studied level of integration of Mali and Nicaragua into world markets by using generalized correction model. It is found that, Nicaragua agriculture market is more integrated than that of Mali. Sekhar (2012) in his study made an attempt to understand degree of integration among selected agricultural markets in India employing co-integration test and Ganzalo - Granger Model. The study indicated absence 
of inter-state or inter- regional restrictions resulted to market integration. Jena (2016) examined market integration and price transmission indices of energy, metal and commodity of India and found existence of long and short run relationship between domestic and international commodity price indices. This findings are similar to studies of Ghosh (2003); Jha, et al. (2005); Rajmal and Misra (2009). The interlinkages between Indian stock and commodity markets using GARACH were analysed by Jhunjhunwala \& Suresh (2020). The results exhibited negative correlation due to rigorous regulatory measures. Similarly, market integration of Euro-Asian markets with Indian capital market were studied by Vijayakumar (2019) and found non-impact on Indian market. The study of Myint (2012) determined market integration and price causality in Myanmar Rice Market by employing Engle Granger and Vector auto-regression (VAR) model however, study could not find market integration of rice markets. Nguyen Thi Duong and Lantican (2009) analysed the degree of integration of rice markets in Vietnam. The study using co-integration test found nine out of 34 rice markets were integrated into a common rice market. Saji (2018) examined price transmission effect from global market to national rubber market by employing Eangel-Granger Co-integration test. The study found higher degree of price integration between national and global markets. Garcia and Salayo (2009) explored interdependencies of aquaculture markets at Philippines by establishing the price co-integration between wholesale and retail prices. The Grangercausality analysis showed that retail prices of milkfish generally led the wholesale prices. Acharya et al. (2012) examined transmission of prices of wheat and rice from international markets to the domestic markets. The study found existence of long - run equilibrium relationship between international and domestic prices of rice and wheat at different market intervals. However, rice markets of eastern India show lack of integration with primary markets of southern India. In the same way, Sendhil et al. (2019) studied wheat price behaviour and the extent of integration among selected wholesale and retail markets in India. The co-integration analysis showed presence of integration between wholesale and retail markets. Tankari and Goundan (2018) explored price transmission of spatial millet in Niger using vector autoregressive model and found non-existence of market integration. Kelbore (2013) examined the integration of Ethiopian grain market using Johansen co-integration and principal component analysis showing both maize and wheat markets integrated with world markets. Ismet et al. (1998) explored degree of market integration and price relationship of Indonesian rice markets and found higher level of market integration of rice. Sendhil et al.(2014) employed co-integration test to analyse linear deterministic trend of onion markets in India. Empirical results revealed existence of strong spatial integration between major onion markets 
of India. On the same note, Iregui and Otero (2017) studied the degree of spatial market integration in Colombia using consumer price index for 153 consumer goods in 13 cities. An econometric analysis of time series showed market integration tends to occur regularly in unprocessed foods products than processed foods. Kilima (2006) analysed transmission of world market prices to local producer prices for sugar, cotton, wheat and rice. The cointegration results indicated prices in Tanzania were not integrated with commodity price of international markets.

The intensive scholastic reviews from aforementioned internationally acclaimed research publications of Mishra and Kumar (2013) ; Praveen and Inbasekar (2015) ; Sekhar (2012) focused on agri-commodities and studies of Nguyen Thi Duong and Lantican (2009); Acharya et al. (2012) ; Sendhil et al. (2019) ; Kelbore(2013) ; Ismet et al.(1998) examined grains and cereals like rice, wheat and others. The evidence from of Jati (2013) ; Upreti et al. (2018) ; Timothy et al. (2014) investigated existence of dynamic relationship and market integration of sugar in India, Kenya, Brazil and Indonesia. However, there exists a dearth of research focusing on market integration of Indian sugar prices with international markets of US, UK and Global prices and its causal effect. This dearth of research motivated the authors to explore market integration of Indian sugar with international markets. This study shall fill existing research gap and intends to contribute for domain knowledge of sugar sector apart from suggesting policy dimensions for remunerative price realization.

\section{Objectives}

Realizing remunerative prices is a motivating factor to stakeholders of sugar trade value chain. In this process, understanding price movements of sugar in domestic and international markets is essential for trade decisions. This study examines market integration of Indian sugar with international sugar markets and global average prices using Johansen's co-integration with VECM model. In addition, the study suggests policy dimensions for realising remunerative prices and for the development of Indian sugar sector.

\section{Theoretical Framework}

The Indian sugar sector is highly regulated by both central and state governments through different pricing policies. Accordingly, prices of sugar are subject to Fair Remunerative Prices (FRP) of central and State Advisory Prices (SAP) of state governments. Under this system, FRP is related to a basic recovery rate of sugar. In addition, in case of greater retrieval of sugar out of sugarcane, farmers shall be paid a premium for the same (CARE, 2019). In India, prices 
of sugar and sugarcane are regulated effecting fluctuation in demand and supply conditions upto 2013. In April 2013, Government of India decontrolled prices of sugar by providing autonomy to the sugar mills to sell sugar in the open market rather than selling it at subsidized prices through Government's public distribution system. Thus, regulated release mechanism for sugar quantity is fixed by the government for open market sale has been eliminated. This sugar price decontrol mechanism resulted to stabilize prices of sugar in domestic market transmitting International white sugar prices. The price of sugar affects production and consumption at Indian and other sugar producing countries. Since 2013, excess sugar production globally led to decline in sugar prices. Sugar prices remained lower for more than 3 years; this resulted to global sugar deficit during 2016-17. The prices of sugar play an indispensable role in production, profitability and stability of global market.

Higher production and decline in sugar prices in the International market resulted to a decline in the sugar prices in the domestic market amounting to Rs.27/kg in May, 2018. Sugar prices are anticipated to be stable due to the measures taken by Government by providing Minimum Support Price as well as by focussing on controlling inflation, higher blending of Ethanol etc. In India, the cane prices are determined by SAP, SMP or FRP based on the policies of the state. FRP is determined by the commission for agriculture costing prices based on cost of production, recovery, expected sugar prices in inter-crop parity, transportation cost and few other factors. The prices are not linked to actual sugar prices determined by the market factors. SAP is determined by states such as Uttar Pradesh, Tamil Nadu, Punjab, Haryana, Uttarkhand and it is not linked to sugar recovery and they are higher than FRP.

Table 3: FRP and SAP prices of Sugarcane (Rs. per Quintal)

\begin{tabular}{|c|c|c|}
\hline Period & FRP & SAP (UP) \\
\hline $2011-12$ & 145 & 240 \\
\hline $2012-13$ & 170 & 280 \\
\hline $2013-14$ & 210 & 280 \\
\hline $2014-15$ & 220 & 280 \\
\hline $2015-16$ & 230 & 280 \\
\hline $2016-17$ & 230 & 305 \\
\hline $2017-18$ & 255 & 315 \\
\hline $2018-19$ & 275 & 315 \\
\hline \multicolumn{3}{|c|}{ (Source: CARE, 2019) } \\
\hline
\end{tabular}

In the sugar season 2018-19, FRP was increased to Rs. 275/ quintal which is about $8 \%$ higher than the FRP paid in 2017-18. UP being the largest producer of sugar cane in India the SAP prices were Rs.315/- per quintal similar to the previous year. Price volatility of sugar is based 
on market conditions. This affected the Indian sugar industry, as the revenue side is not determined and raw material side is controlled. Declining prices of sugar in the past had resulted to unaffordable FRP's by the sugar mills.

\section{Data and Methodology}

This study adopting causal research method used secondary data of sugar prices at India, London, USA and Global average. Monthly sugar prices of 556 data variables from January 2009 to July 2020 are considered for the study. The secondary data is collected from web portals of ICE commodity exchanges at USA and London (UK) and Ministry of Consumer Affairs, Government of India to ensure authenticity of data and the same has been converted into sugar price per kg to ensure uniformity of measurement. This study employed Augmented Dicky Fuller test for checking the stationary. Akaike Information Criterion has been used for selecting optimal lag order. Subsequently, Johansen's co-integration test has been administered for investigating co-integration. Based on the result, VECM test has been used for analysing long and short term casual impact with $\mathrm{R}$ statistical package. The test of Augmented Dickey Fuller (ADF) is used with the following regression equation:

$$
\begin{aligned}
& \Delta y_{t}=a+\alpha y_{t-1}+\sum_{i=1}^{k} b_{i} \Delta y_{t-i}+\varepsilon_{t} \\
& \Delta y_{t}=a+\beta t+\alpha y_{t=1}+\sum_{i=1}^{k} b_{i} \Delta y_{t-i}+\varepsilon_{t}
\end{aligned}
$$

The unit root in $y_{t}$ where $\Delta y_{t-i}$ is the lagged difference to accommodate serial correlation in the errors $\varepsilon_{t} . k$ is the appropriate lag length.

Johansen's co integration validated relationship between variables at level. Hence, VAR model with VECM environment has been used to understand the casual relationship of selected variables. Vector Error Correction Model is a restricted Vector Auto Regression used with non stationary series are known to be co-integrated. The co-integrating equation is as under:

$y_{2, t}=\beta y_{1, t}$

The corresponding VECM model is

$$
\begin{aligned}
& \Delta y_{1, t}=\alpha_{1}\left(y_{2, t-1}-\beta y_{1, t-1}\right)+\epsilon_{1, t} \\
& \Delta y_{2, t}=\alpha_{2}\left(y_{2, t-1}-\beta y_{1, t-1}\right)+\epsilon_{2, t}
\end{aligned}
$$




\section{Analysis}

The descriptive statistics of selected variables under the study such as mean, median, standards deviation, kurtosis, skewness etc. are presented in the table 4. The mean value of Indian and global sugar prices are higher compared to London and US prices indicating existence of price gap. The variance and standard deviation are greater in Indian and Global sugar prices. Accordingly, the skewness of Indian sugar prices shows negative value than other international prices. However, kurtosis displays negative amongst London and global sugar prices.

Table 4: Descriptive Statistics

\begin{tabular}{|l|c|c|c|c|}
\hline Particulars & ISP & LSP & USSP & GSP \\
\hline Minimum & 21.13 & 0.2968 & 0.2291 & 13.68 \\
\hline Maximum & 43.48 & 0.7988 & 0.7490 & 32.71 \\
\hline 1. Quartile & 32.75 & 0.3652 & 0.2902 & 19.44 \\
\hline 3. Quartile & 39.22 & 0.5536 & 0.4364 & 24.58 \\
\hline Mean & 35.72 & 0.4705 & 0.3846 & 22.22 \\
\hline Median & 36.20 & 0.4566 & 0.3602 & 21.55 \\
\hline Sum & 4965.77 & 65.4078 & 53.46 & 3088.78 \\
\hline SE Mean & 0.3884 & 0.0104 & 0.0100 & 0.3317 \\
\hline LCL Mean & 34.95 & 0.4499 & 0.3648 & 21.56 \\
\hline UCL Mean & 36.49 & 0.4911 & 0.4044 & 22.87 \\
\hline Variance & 20.97 & 0.0150 & 0.0139 & 15.30 \\
\hline Stdev. & 4.57 & 0.1226 & 0.1181 & 3.91 \\
\hline Skewness & -0.6589 & 0.7239 & 0.9733 & 0.3243 \\
\hline Kurtosis & 0.3474 & -0.3696 & 0.3204 & -0.3852 \\
\hline
\end{tabular}

(Source: Authors' calculations)

Figure 2: Sugar Prices

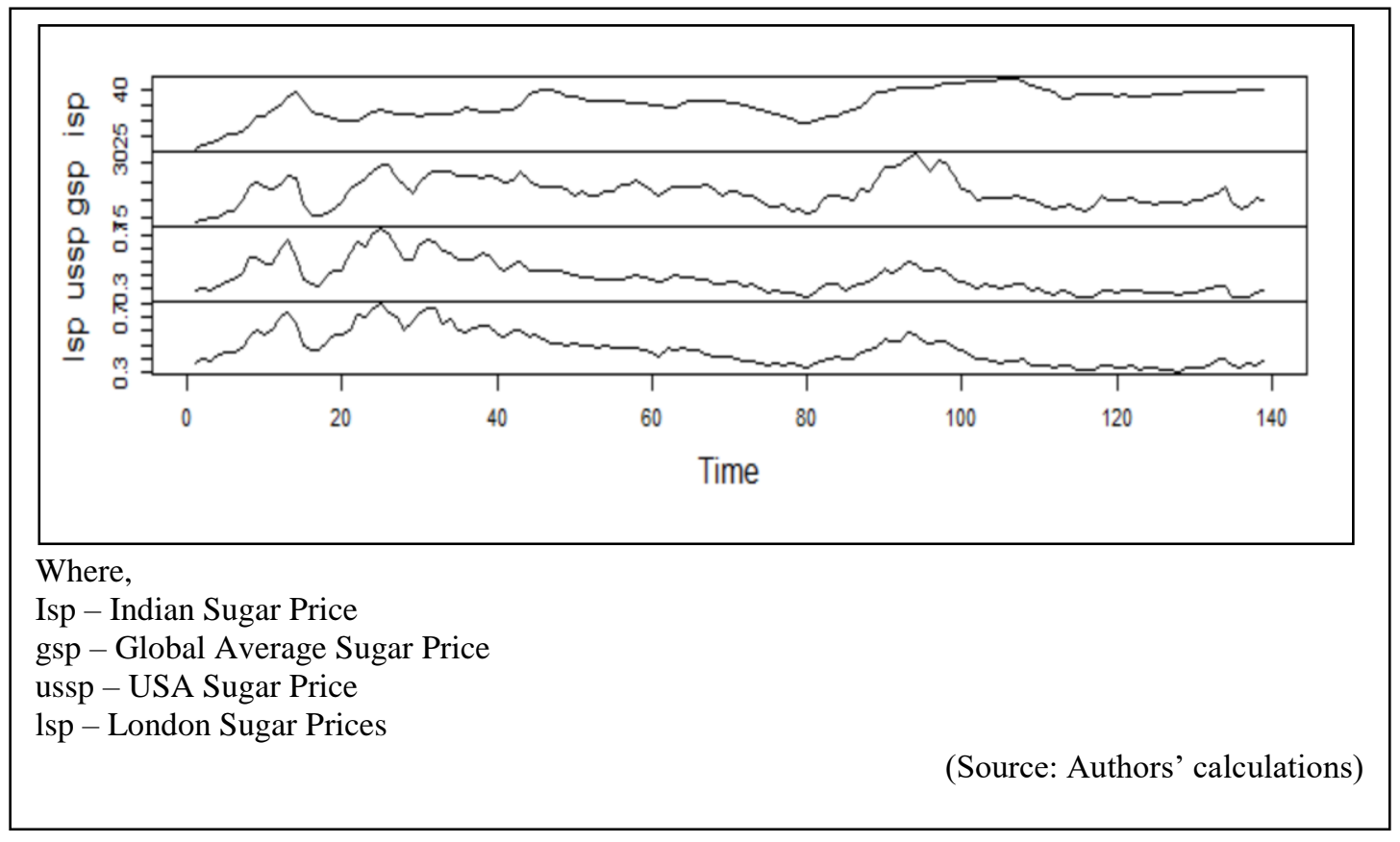


The variables of Indian, global average, USA and UK sugar price movements has been portrayed in Figure 2.

\section{Test of stationary}

Selected variables under the study found to be stationary at the level with the help of Augmented Dickey Fuller Test as shown in Table no.5. Further, the study using lag order selection method identified appropriate lag number 2 as per Akakie Information Criterion ($1.522996 \mathrm{e}+01)$ as compared to Hannan-Quinn Information Criterion $(-1.490568 \mathrm{e}+01)$, Schwarz Information Criterion (-1.443187e+01) and Final Prediction Error (2.432807e-07).

Table 5: Test of Stationary

\begin{tabular}{|c|l|c|c|}
\hline Sl.no & Variable & T-statistics & P-value \\
\hline 1 & India & -3.9195 & 0.0152 \\
\hline 2 & Global & -3.9741 & 0.0126 \\
\hline 3 & USA & -3.8297 & 0.0196 \\
\hline 4 & London & -3.6163 & 0.0344 \\
\hline \multicolumn{3}{|c}{ (Source: Authors' calculations) }
\end{tabular}

\section{Johansen's Co-integration Test}

The study considering the stationarity of selected variables at the level administered Johansen's co-integration test with identified lag order criteria 2 to understand long and short run causal relationship. The critical value of Trace and Max Eigen test statistics of Indian sugar prices with international prices trading at London, US and global average sugar prices are shown in table 6 and 7.

\section{Table 6: Trace Statistics}

\begin{tabular}{|c|c|c|c|c|}
\hline & test & 10pct & 5pct & 1pct \\
\hline $\mathbf{r}<=\mathbf{3}$ & 02.97 & 07.52 & 09.24 & 12.97 \\
\hline $\mathbf{r}<=\mathbf{2}$ & 14.68 & 17.85 & 19.96 & 24.60 \\
\hline $\mathbf{r}<=\mathbf{1}$ & 30.65 & 32.00 & 34.91 & 41.07 \\
\hline $\mathbf{r = 0}$ & 62.74 & 62.74 & 53.12 & 60.16 \\
\hline \multicolumn{4}{|c|}{} & \multicolumn{3}{|c|}{ (Source: Authors' calculations) } \\
\hline
\end{tabular}

The statistical result of test value (62.74) is more than critical value (53.12) indicating to reject null hypothesis, i.e., there is no co-integration amongst selected sugar prices. It is therefore, the study accepts alternative hypothesis of existence of co-integration. 
Table 7: Eigen Statistics

\begin{tabular}{|c|c|c|c|c|}
\hline & test & 10pct & 5pct & 1pct \\
\hline $\mathbf{r}<=\mathbf{3}$ & 2.97 & 7.52 & 9.24 & 12.97 \\
\hline $\mathbf{r}<=\mathbf{2}$ & 11.70 & 13.75 & 15.67 & 20.20 \\
\hline $\mathbf{r}<=\mathbf{1}$ & 15.97 & 19.77 & 22.00 & 26.81 \\
\hline $\mathbf{r}=\mathbf{0}$ & 32.10 & 25.56 & 28.14 & 33.24 \\
\hline \multicolumn{4}{|c}{} \\
\hline \multicolumn{4}{|c|}{ (Source: Authors' calculations) } \\
\hline
\end{tabular}

The calculated statistical results is greater (32.10) than critical value of 5\% (28.14). This results advices to reject null hypothesis of no-co integration amongst selected sugar prices of the study. From the above two statistical results of Trace and Eigen values, the study suggest for accepting alternative hypothesis of existence of co-integration amongst the sugar prices of India, Global, USA and London.

\section{Vector error correction model (VECM)}

The study considering the existence of co-integration under Johansen test administered VECM model to understand long and short run causal relationship of Indian and International sugar prices. The statistical results in the table 8 indicate error correction term and $\mathrm{P}$ values. In order to satisfy the condition of existence of long-term causality, the error correction term in the model should be negative and probability value should be significant.

Table 8: VECM Model

\begin{tabular}{|l|c|c|c|c|c|c|}
\hline & ECT & Intercept & ISP-1 & LSP-1 & USSP-1 & GSP-1 \\
\hline Equation & -0.0060 & 0.2975 & 0.4933 & 9.5806 & -2.1601 & 0.0717 \\
ISP & $(0.0052)$ & $(0.2038)$ & $(0.0882)^{* * *}$ & $(4.4840)^{*}$ & $(4.1873)$ & $(0.0686)$ \\
\hline Equation & 0.0002 & -0.0092 & 0.0087 & -0.2722 & 0.4379 & 0.0042 \\
LSP & $(0.0002)$ & $(0.0087)$ & $(0.0037)^{*}$ & $(0.1906)$ & $(0.1780)^{*}$ & $(0.0029)$ \\
\hline Equation & 0.0008 & -0.0311 & 0.0070 & 0.0467 & 0.2393 & 0.0052 \\
USSP & $(0.0003)^{* *}$ & $(0.0100)^{* *}$ & $(0.0043)$ & $(0.2202)$ & $(0.2056)$ & $(0.0034)$ \\
\hline Equation & 0.0239 & -0.8460 & 0.0834 & 5.6015 & 24.3643 & -0.1317 \\
GSP & $(0.0090)^{* *}$ & $(0.3548)^{*}$ & $(0.1535)$ & $(7.8047)$ & $(7.2882)^{* *}$ & $(0.1194)$ \\
\hline & & & ISP-2 & LSP-2 & USSP-2 & GSP-2 \\
\hline & & & -0.0912 & 7.8541 & -8.4444 & -0.0162 \\
& & & $(0.0818)$ & $(4.0971)$ & $(4.1326)^{*}$ & $(0.0605)$ \\
\hline & & & -0.0062 & 0.1359 & -0.4648 & 0.0002 \\
& & & $(0.0035)$. & $(0.1741)$ & $(0.1757)^{* *}$ & $(0.0026)$ \\
\hline & & & -0.0043 & 0.1415 & -0.4695 & 0.0015 \\
& & & $(0.0040)$ & $(0.2012)$ & $(0.2029)^{*}$ & $(0.0030)$ \\
\hline & & & -0.0163 & 3.6499 & -5.9900 & -0.0332 \\
& & & $(0.1424)$ & $(7.1312)$ & $(7.1931)$ & $(0.1054)$ \\
\hline
\end{tabular}

Accordingly, the coefficient of Indian sugar prices is negative with p-value less than 0.05 indicating statistically significant at $5 \%$ level. The study, therefore, finds existence of long run 
causality on Indian sugar prices from London, US and global average. Similarly, in terms of short term causality Indian sugar prices have impact on its own immediate previous prices with lag one to extent of $49.33 \%$.

The VECM model led to generate co-integration equation -

$$
\operatorname{ISP}(1)=\operatorname{LSP}(578.884)+\operatorname{USSP}(-587.987)+G S P(-2.006)
$$

The above equation conveys that Indian sugar price are positively associated with London and negatively associated with United States and Global sugar prices.

\section{Discussion}

The study based on statistical results of Johansen test of co-integration finds existence of market integration amongst Indian sugar prices with international markets of US, UK and global average prices. Further, the Vector Error Correction Model under VAR environment confirms existences of long run causal effect with negative error correction term (-0.0060) and statistically significant p-value (0.0052) indicating market integration. In addition, the test statistics confirms short run causal effect on Indian sugar prices from its own previous prices of lag 1. Similarly, London sugar prices have impact on Indian prices with a lag 1 showing significance at 5\%. Whereas, sugar prices USA and Global average do not have any short term causal impact on Indian prices. However, in practice, the government of India and state governments announces Fair Remunerative Prices (FRP) and State Advisory Prices (SAP) considering the international sugar price movements to protect the interest of stakeholders of the sector. In addition, governments are also adopting several policies and promotional measures considering its contributions to rural industrialization, employment opportunities and socio-economic development of agri-farming sector. However, sugar mills have a challenging time to pay cane dues as per the government announced prices to cane growers considering international market uncertainties of sugar production and demand from other countries. Figure 3 refers to arrears of sugar mills to farmers. 
Figure 3: Arrears

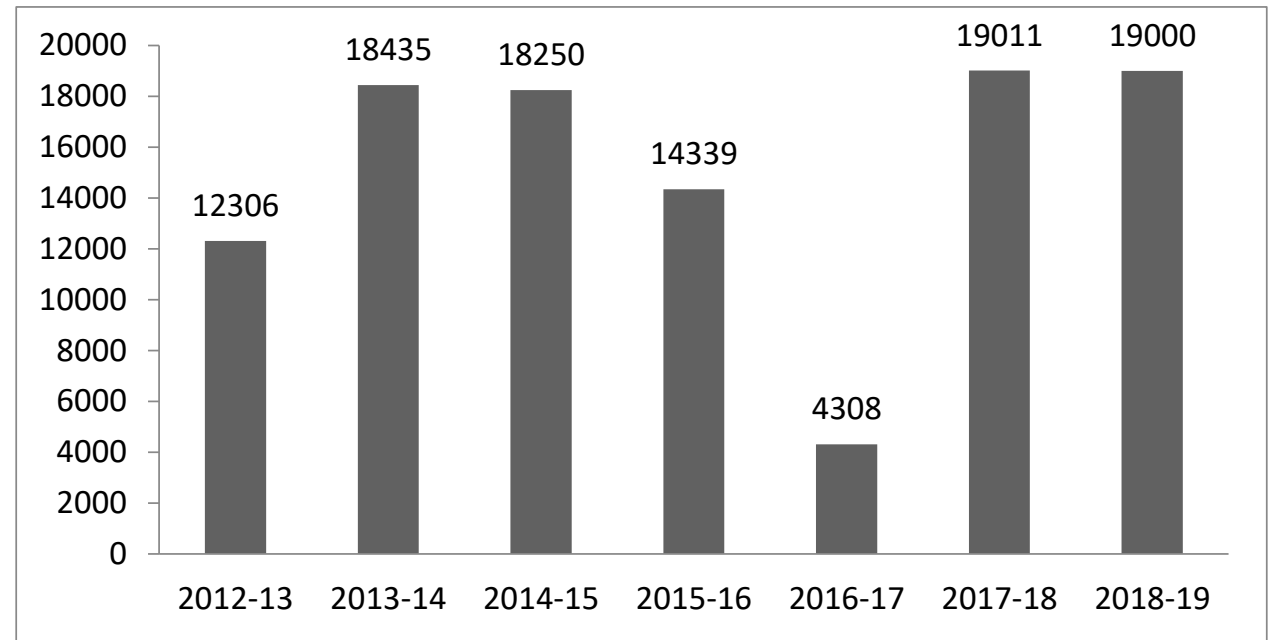

(Source: FAO, 2019)

The above figure 3 evidenced mounting financial burden on sugar mills over a period. It is, therefore, they should focus on improving financial performances in order to self-sustain and reduce the dependency on government fiscal support. In this regard, companies may consider government's national policy of bio-fuel to increase scope of sugar factories to produce ethanol beyond sugarcane molasses, sugar cane, sugar beat, starch etc. This ethanol production shall stabilize the revenue stream of the sugar sector considering the revised prices by the government to cope up declining sugar prices due to increase in production. Generally, ethanol is blended in the fuel in order to reduce country's dependency on crude oil imports. Indian sugar mills, therefore, should focus on enhancing production of ethanol by lowering production of sugar. This could encourage governments objective of providing cleaner fuel by blending of ethanol with motor spirits in order to reduce pollution, conserve foreign exchange, increase value addition in the sugar industry and enabling them to clear cane prices. In this way, sugar industry needs to enhance technology and improve capacities for ethanol production to tap the potential of Indian sugar sector and achieve the target of ethanol blending policy apart from contributing for accelerating economic growth.

\section{Conclusion}

India's sugar production is leading towards recording a highest yield for sugarcane as a result of assured government-mandated fair price from sugar mills to farmers, thus encouraging sugar cane production. This study evaluated sugar prices to understand market integration with global markets and found existence. Indian prices of sugar are comparatively higher than other markets in spite of increasing production in the country with the government support. The sugar mills are unable to realize remunerative prices of sugar through exports due to lower cane prices 
in Brazil, Australia and Thailand. This would affect revenue streams and results in accumulation of outstanding dues to cane growers. Hence, Indian sugar sector should focus on producing ethanol and contributing to reduce countries crude oil demand rather than increasing sugar production. A similar kind of shift-in strategy in production from sugar to ethanol has been adopted by Brazil, during higher fuel prices and to reduce dependency on crude oil imports. Indian sugar mills may consider adapting similar strategy to make use of competitive advantage and contribute to the growth of Indian economy. Further research on Indian sugar sector competitiveness on promoting socio-economic development of rural areas, reducing cost of production for by-products to optimise revenue streams etc., may be explored.

\section{Managerial Implications}

Indian sugar manufacturing companies with increase in production of sugar is posing a challenge to government's fiscal policies for continuous support to the sector by procuring sugar at fair prices. The management of sugar factories considering findings of this study on market integration of domestic sugar with international prices as well as the competition from low cost cane producing countries of Brazil, Australia and Thailand need to focus on enhancing revenues from alternative modes. In this way, sugar industry may consider to act as energy complexes by engaging themselves in the production of ethanol, power and other by-products. This mechanism enables sugar mills to pay remunerative prices to cane growers apart from improving their financial performances and achieve the target of ethanol blending policy apart from contributing for accelerating economic growth. 


\section{Acknowledgement}

"The authors are grateful to the editor and anonymous referees of the journal for their extremely useful suggestions to improve the quality of the paper. Usual disclaimers apply."

\section{References}

1. Acharya, S. S., Chand, R., Birthal, P. S., Kumar, S., \& Negi, D. S. (2012). Market Integration and Price Transmission in India: A Case of Rice and Wheat with Special Reference to the World Food Crisis of 2007/08. Food and Agriculture Organization, 1-63. www.fao.org/3/a-an034e.pdf

2. Baquedano, F. G., Liefert, W., \& Shapouri, S. (2011). World market integration for export and food crops in developing countries: A case study for Mali and Nicaragua. Agricultural Economics, 42(5), 619-630. https://doi.org/10.1111/j.15740862.2011.00540.x

3. Boffa, M., \& Varela, G. J. (2019). Integration and Price Transmission in Key Food Commodity Markets in India. February.

4. Garcia, Y. T., \& Salayo, N. D. (2009). Price Dynamics and Cointegration in the Major Markets of Aquaculture Species in the Philippines. Asian Journal of Agriculture and Development, 6(1), 49-81.

5. Ghosh, M. (2003). Spatial integration of wheat markets in India: Evidence from cointegration tests. Oxford Development Studies, 31(2), 159-171. https://doi.org/10.1080/13600810307426

6. Iregui, A. M., \& Otero, J. (2017). Testing for spatial market integration: evidence for Colombia using a pairwise approach. Agricultural Economics (United Kingdom), 48(6), 1-11. https://doi.org/10.1111/agec.12371

7. Ismet, M., Barkley, A. P., \& Llewelyn, R. V. (1998). Government intervention and market integration in Indonesian rice markets. Agricultural Economics, 19(3), 283295. https://doi.org/10.1111/j.1574-0862.1998.tb00532.x

8. Jati, K. (2013). Sugar Commodity Price Analysis: Examining Sugar Producer Countries. International Journal of Trade, Economics and Finance, 4(5), 288-295. https://doi.org/10.7763/ijtef.2013.v4.303

9. Jena, P. K. (2016). Commodity market integration and price transmission: Empirical evidence from India. Theoretical and Applied Economics, 23(3), 283-306.

10. Jha, R., Murthy, K. V. B., \& Sharma, A. (2005). Market Integration in Wholesale Rice 
Markets in India. https://doi.org/10.1057/9780230228337

11. Jhunjhunwala, S., \& Suresh, S. (2020). Commodity and Stock Market Interlinkages: Opportunities and Challenges for Investors in Indian Market. Global Business Review. https://doi.org/10.1177/0972150920946413

12. Kelbore, Z. G. (2013). Transmission of World Food Prices to Domestic Market: The Ethiopian Case. 1-53.

13. Kilima, F. T. M. (2006). Are Price Changes in the World Market Transmitted to Markets in Less Developed Countries? A Case Study of Sugar, Cotton, Wheat, and Rice in Tanzania. IIIS Discussion Paper No. 160. https://doi.org/10.2139/ssrn.925683

14. Mishra, R., \& Kumar, A. (2013). The spatial integration of vegetable markets in Nepal. Asian Journal of Agriculture and Development, 8(1), 101-114.

15. Myint, T. (2012). Market Integration and Price Causality in the Myanmar Rice Market. Asian Journal of Agriculture and Development, 7(2), 91-105. http://ideas.repec.org/a/sag/seajad/v7y2010i2p91-105.html

16. Nguyen Thi Duong, N., \& Lantican, F. A. (2009). Spatial integration of rice markets in Vietnam. Asian Journal of Agriculture and Development, 6(1), 13-28.

17. Parwez, S. (2016). A Conceptual Model for Integration of Indian Food Supply Chains. Global Business Review, 17(4), 1-17. https://doi.org/10.1177/0972150916645681

18. Praveen, K. V., \& Inbasekar, K. (2015). Integration of Agricultural Commodity Markets in India. International Journal of Social Sciences, 4(1), 51. https://doi.org/10.5958/2321-5771.2015.00004.6

19. Rajmal, \& Misra, S. (2009). Transmission from International Food Prices to Domestic Food Prices - The Indian Evidence. Reserve Bank of India, Department of Economic Analysis and Policy, 1-37.

20. Saji, T. G. (2018). Price transmission for natural rubber: India integration with world markets. Theoretical and Applied Economics, 25(4), 155-168.

21. Sekhar, C. S. C. (2012). Agricultural market integration in India: An analysis of select $\begin{array}{llll}\text { commodities. } & \text { Food } & \text { 30licy, } 322 .\end{array}$ https://doi.org/10.1016/j.foodpol.2012.03.002

22. Sendhil, R., Arti, T., Lal, P., Gururaj, B. M., Jamaludheen, A., Chaudhary, U., \& Rathore, R. (2019). Price dynamics and extent of integration in Indian wholesale and retail wheat markets. Journal of Agricultural Science and Technology, 21(3), 517-530.

23. Sendhil, R., Sundaramoorthy, C., Venkatesh, P., \& Thomas, L. (2014). Testing market integration and convergence to the law of one price in Indian onions. African Journal 
of Agricultural Research, 9(40), 2975-2984. https://doi.org/10.5897/ajar2013.8037

24. Tankari, M. (2012). Global price transmission in Senegal's groundnut markets: can smallholders bene t from high international prices? Munich Personal RePEc Archive, $1-16$.

25. Tankari, M. R., \& Goundan, A. (2018). Nontraded food commodity spatial price transmission: evidence from the Niger millet market. Agricultural Economics (United Kingdom), 49(2), 147-156. https://doi.org/10.1111/agec.12404

26. Timothy, O. O., Hillary, B. K., Job, L. K., \& Geoffrey, S. K. (2014). Analysis of Market Integration : A Case of Sugar in Selected Markets in Kenya. Journal of Economics and Sustainable Development, 5(2), 197-204.

27. Upreti, P., Singh, A., Jha, G. K., \& Nithyashre, M. L. (2018). An Economic Analysis of Price Behavior, Efficiency and Market Integration of Sugar in India. 179-188.

28. Varela, G., Carroll, E. A., \& Iacovone, L. (2013). Determinants of Market Integration and Price Transmission in Indonesia. Policy Research Paper 6098, 1-36. https://doi.org/10.1355/ae30-1b

29. Vijayakumar, A. N. (2019). Impact of Euro-Asian Markets on Indian Capital Market. Journal of Commerce \& Accounting Research, 8(4), 47-61.

\section{Conferences, reports and websources}

30. CARE (2019) Ethanol - A vital Cog for sustenance of India sugar sector, CARE Ratings Webinar on Indian Sugar Sector.

31. DFPD (2019) Annual reports 2018-19, Department of Food and Public Distribution (DFPD), Ministry of Consumer Affairs, Food \& Public Distribution, Government of India.

32. Price Policy for Sugarcane, Government of India, 2018-19.

33. USDA (2019) Sugar: World Markets and Trade, Foreign Agricultural Service/USDA 3, Office of Global Analysis.

34. http://www.fao.org/economic/est/est-commodities/sugar/en/(Accessed 10 Decemeber 2019)

35. https://www.usda.gov/ (Accessed 10 Decemeber 2019) 